\title{
INVERSE MODELING OF VADOSE ZONE FLOW PROCESSES USING SQUARED $\varepsilon$-INSENSITIVITY LOSS FUNCTION
}

\author{
NAVIN K. C. TWARAKAVI ${ }^{1 *}$, HIROTAKA SAITO ${ }^{2)}$, \\ JIRKA ŠIMU゚NEK ${ }^{3)}$, M. TH. VAN GENUCHTEN ${ }^{4)}$ \\ ${ }^{1 *}$ Corresponding Author Agronomy and Soils Department, Auburn University, Auburn, AL-36832; Mailto: twarakavi@auburn.edu \\ 2) Department of Ecoregion Science, Tokyo University of Agriculture and Technology, Fuchu, Tokyo. \\ ${ }^{3)}$ Department of Environmental Sciences, University of California Riverside, Riverside, CA. \\ ${ }^{4)}$ Department of Mechanical Engineering, COPPE/LTTC, Federal University of Rio de Janeiro, UFRJ, Rio de Janeiro, RJ CEP \\ 21945-970, Brazil.
}

An accurate representation of reality in numerical variably-saturated flow models requires reliable estimates of necessary model parameters. Inverse modeling seeks to estimate parameters such as the saturated and residual water contents, the saturated hydraulic conductivity, the shape parameters of the soil hydraulic functions, using easily attainable observations of actual or cumulative water fluxes, pressure heads, water contents, and concentrations. The inverse procedure usually combines the nonlinear leastsquares-based (SSQ) parameter optimization method with a numerical solution of the variably-saturated flow and transport equations. The SSQ-based inverse method is however sensitive to outliers. A novel Squared $\varepsilon$-Insensitive Loss Function (SILF) approach is introduced in this study. The SILF approach is inspired by the $\varepsilon$-insensitive loss function proposed by Vapnik (1995). The objective function used in the SILF approach is similar to the least-squares objective function, except that it penalizes only for errors greater than a certain predefined acceptable error term $\varepsilon$. The SILF approach shows an improved performance over the SSQ approach in estimating the soil hydraulic parameters. Apart from providing robust estimates of the soil hydraulic parameters, the SILF approach also gives an approximation of the relative measurement error during sampling.

KEY WORDS: Vadose Zone, Inverse Problem, Insensitivity Loss Function.

Navin K. C. Twarakavi, Hirotaka Saito, Jirka Šimůnek, M. Th. Van Genuchten: INVERZNÉ MODELOVANIE PRÚDENIA VODY VO VODOU NENASÝTENEJ PÔDE S POUŽITÍM NECITLIVOSTNEJ STRATOVEJ FUNKCIE \&. J. Hydrol. Hydromech., 58, 2010, 3; 33 lit., 5 obr., 3 tab.

Presná reprezentácia skutočností v numerických modeloch prúdenia vo vodou nenasýtenej pôde vyžaduje spol'ahlivé určenie potrebných parametrov modelu. Inverzným modelovaním sa snažíme o určenie takých parametrov, ako sú reziduálna vlhkost' pôdy, nasýtená hydraulická vodivost', tvarové parametre hydraulických funkcií pôdy, využijúc l'ahko realizovatel'né pozorovania momentálnych alebo kumulatívnych tokov vody, tlakových výšok, vlhkostí pôdy a koncentrácií rozpustených látok. Inverzná procedúra obyčajne kombinuje nelineárnu optimalizáciu parametrov založenú na metóde najmenších štvorcov (SSQ) s numerickým riešením transportných rovníc vo vodou nenasýtenej pôde. Táto metóda (SSQ) je však citlivá na náhodné chyby. Nová, necitlivostná stratová funkcia s necitlivost'ou $\varepsilon($ SILF), použitá v tejto štúdii, bola inšpirovaná návrhom publikovaným Vapnikom (1995).

Optimalizovaná funkcia použitá v prístupe SILF je podobná tej, ktorá sa používa v metóde najmenších štvorcov s tou výnimkou, že táto penalizuje len chyby väčšie ako je určitá preddefinovaná akceptovatel'ná chyba $\varepsilon$. Pri určovaní hydraulických parametrov pôdy táto metóda SILF preukázala svoje prednosti pred prístupom SSQ. Okrem toho, že metóda SILF dáva robustné odhady hydraulických parametrov pôdy, umožňuje tiež aproximáciu relatívnych chýb merania počas odberu vzoriek.

KLUUČOVÉ SLOVÁ: vodou nenasýtená pôda, inverzný problém, necitlivostná stratová funkcia. 


\section{Introduction}

Experimental determination of soil hydraulic properties relating the soil water content, the capillary pressure head, and the hydraulic conductivity can often be a time-consuming and work-intensive process (Klute and Dirksen, 1986; Dirksen, 1991). As a result, detailed characterization of soil hydraulic functions required for accurate model predictions of water flow in the heterogeneous vadose zone is seldom done. On the other hand, information about soil-water pressure heads and moisture contents (also referred to as state variables) can be obtained readily and economically using instruments such as tensiometers, neutron probes, and/or time domain reflectometry (TDR). The availability of state information, such as moisture contents, pressure heads and fluxes, in field-scale vadose zone studies is therefore much more common than knowledge of soil hydraulic properties. As a result, much research effort has been devoted to estimating soil hydraulic parameters using this so-called state information. The utilization of state information (i.e., water content and pressure head data) to infer model parameters is the quintessence of a class of modeling techniques referred to as "inverse problems".

In the past two decades, a number of inverse modeling studies for estimating soil hydraulic parameters in the vadose zone has been published (e.g., Kool et al. 1985; Kool and Parker 1987; Eching and Hopmans 1993; van Dam et al. 1994; Šimuinek and van Genuchten 1996, Hopmans et al., 1997, Vrugt et al., 2008). The inverse-problembased parameter estimation technique involves the indirect estimation of soil hydraulic functions using repeated numerical solutions of the governing flow equation for variable-saturated water flow, such as the Richards equation (Richards, 1931; Jury et al., 1991), with different parameter sets, and comparing computed results with experimental observations. The Richards equation is first solved numerically using the parameterized soil hydraulic functions with initial estimates for their parameters. These parameters are then optimized by minimization of the objective function that contains the sum of squared deviations between observed and predicted state variables, using repeated numerical simulations of the flow process (Hopmans et al., 2002). This iterative inversion of the flow equation in numerical models is in contrast to direct inversion techniques used in analytical solutions (Yeh, 1986).
To summarize, numerical inverse estimation techniques involve the coupling of a numerical model of flow with a parameter optimization algorithm such as the Marquardt-Levenberg method (Marquardt, 1963) or various global optimization methods (e.g., Vrugt et al., 2008).

Let $\tilde{y}=\left\{\tilde{y}_{1}, \tilde{y}_{2}, \ldots, \tilde{y}_{q}\right\}$ denotes the vector of observed state variables of size $q$ (such as water contents, pressure heads, fluxes) at various locations and times and $Y(\delta)=\left\{Y_{1}(\delta), Y_{2}(\delta), \ldots, Y_{q}(\delta)\right\}$ denotes the corresponding model predictions using a parameter set $\delta=\left\{\delta_{1}, \delta_{2}, \ldots, \delta_{s}\right\}$ of size $s$ such that

$\delta \in \Theta \subseteq \mathfrak{R}^{s}$,

where $\mathfrak{R}^{s}$ represents the $s$-dimensional Euclidean space and $\Theta$ denotes the feasible parameter space that is predefined in the model using reasonable upper and lower bounds for each parameter (Vrugt et al., 2005). The prediction efficiency of the inverse model with a given parameter set $\delta$ is represented by the residual vector $E(\delta)$, which is linear/non-linear transformation of differences between the observed data, $\tilde{y}$, and the model predictions, $Y(\delta)$ :

$$
E(\delta)=\gamma(Y(\delta), \tilde{y})=\left\{e_{1}(\delta), e_{2}(\delta), \ldots . e_{q}(\delta)\right\}
$$

where $\gamma($.$) is a user-defined linear/non-linear trans-$ formation function. In an inverse problem, one estimates the "best parameter set" by minimizing some kind of a lumped estimate (referred to as the objective function) from the residual vector $E(\delta)$ such that model predictions are as close as possible to corresponding observed values (Vrugt et al., 2005).

The choice of the objective function is important for a reliable estimation of model parameters. One of the commonly used objective functions is the Sum of Squared Residuals (SSQ) which is based on non-linear least squares. Essentially, the SSQ objective function is the sum of residuals wherein the residual is the quadratic transformation of the difference between the observed data and model predictions:

$$
\operatorname{SSQ}(E(\delta))=\sum_{i=1}^{q} W_{i}\left[Y_{i}(\delta)-\tilde{y}_{i}\right]^{2},
$$

where $W_{i}$ is a weight vector $(i=1 . . q)$ that assigns a degree of importance to each residual. Popularly used inverse formulations, such as those used in the HYDRUS suite of softwares (Šimuinek et al., 2005, 
2008), employ the weighted SSQ as the objective function to estimate the best parameter set.

Non-linear least squares-based objective functions infer parameters by minimizing the sum of the weighted squared differences between the observed state variables and those calculated by a mathematical model. A detailed literature review reveals that non-linear least-squares-based objective functions (such as SSQ) have been the most widely used objective functions for parameter optimization in hydrological sciences (Hopmans et al., 2002). However, Finsterle and Najita (1998) have questioned the robustness of the least-squares criterion because of the tendency of outliers in the measurements to strongly influence the outcome of the inverse modeling. Finsterle and Najita (1998) compared other robust estimators to the standard leastsquares objective function. It was observed that robust estimators decreased relative weights of outliers and thus made the estimated parameters less affected by the presence of non-gaussian and gaussian errors (Šimuinek and Hopmans, 2002).

While significant attention has been given to addressing outliers in data sets during optimization, measurement errors that are a result of detection limits and sensitivity of a particular instrument have been assumed to be negligible and ignored in the past. In this paper, we propose a new approach to handle measurement errors in datasets in inverse problems by using a new objective function called the Squared $\varepsilon$-Insensitive Loss Function (SILF) proposed by Vapnik (1995). The SILF function is defined as follows:

$$
\operatorname{SILF}(E(\delta), \varepsilon)=\sum_{i=1}^{q} W_{i} l_{i}^{2}(\delta)
$$

where

$$
l_{i}(\delta)= \begin{cases}\left|Y_{i}(\delta)-\tilde{y}_{i}\right|-\varepsilon & \left|Y_{i}(\delta)-\tilde{y}_{i}\right|>\varepsilon \\ 0 & \left|Y_{i}(\delta)-\tilde{y}_{i}\right| \leq \varepsilon\end{cases}
$$

where $\varepsilon$ is an optimally selected parameter called the acceptable error. Fig. 1 compares the SILF and SSQ objective functions. The SILF objective function is very similar to the SSQ objective function except that residuals smaller than $\varepsilon$ are considered to be insignificant. Similarly to SSQ, a quadratic transformation is used for residuals greater then $\varepsilon$ (Vapnik, 1995). One may observe that the SILF objective function attains the form of the SSQ objective function for the acceptable error equal to zero $(\varepsilon=0)$. The performance of SILF objective functions has been compared to traditional objec- tive functions (SSQ, Absolute Mean) in previous studies (e.g., Hastie et al., 2001), in which SILF was shown to improve the fit between predicted and observed data. Previous studies have shown an improved fit of observed data when the SILF objective with a non-zero acceptable error was used, indicating that the SSQ objective function may not necessarily lead to the best possible parameter estimate (e.g., Kwok and Tsang, 2003). In this paper, we analyze the robustness of the SILF approach for inverse modeling of vadose zone flow processes.

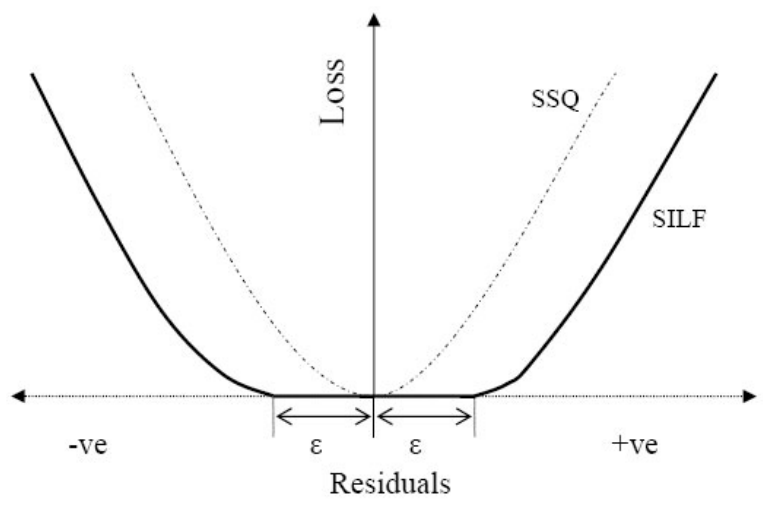

Fig. 1. Significance of residuals to the value of SSQ and SILF objective functions.

Obr. 1. Význam reziduálov vzhl’adom k hodnotám funkcií SSQ a SILF.

\section{Theory}

\section{Governing equations and numerical modeling}

Variably-saturated flow in soils is a highly nonlinear and dynamic phenomenon. Commonly used numerical models for variably-saturated water flow in the vadose zone typically employ the classical Richards equation (Richards, 1931). For a one-dimensional scenario, the Richards equation is described mathematically as follows:

$$
\frac{\partial \theta}{\partial t}=\frac{\partial}{\partial z}\left[K(h) \frac{\partial h}{\partial z}-K(h)\right]-S
$$

where $\theta$ is the volumetric water content $[-], h-$ the soil water pressure head [L], $t$ - time $[\mathrm{T}], z-$ the distance from reference datum [L], $K(h)$ - the unsaturated hydraulic conductivity as a function of $h$ or $\theta\left[\mathrm{L} \mathrm{T}^{-1}\right]$, and $S$ is the sink term usually accounting for the root water uptake.

A high nonlinearity in the variably-saturated water flow equation exists due to the dependence of the hydraulic conductivity, $K(h)$, and the water content, $\theta(h)$, on the pressure head, $h$. Conse- 
quently, modeling of variably-saturated water flow involves solving Eq. (5) along with a nonlinear model that characterizes relationships between the water content, pressure head, and unsaturated hydraulic conductivity. The Gardner exponential model (Gardner, 1958), the Brooks and Corey model (Brooks and Corey, 1964) and the van Genuchten-Mualem model (van Genuchten, 1980) are among the most widely used approaches to represent the dependence of the hydraulic conductivity and the water content on the capillary pressure head. Readers are referred to Leij et al. (1997) for a detailed discussion on the most commonly used soil hydraulic models. Of all available soil hydraulic models, the van Genuchten-Mualem model (van Genuchten, 1980) is perhaps the most widely used model to characterize the hydraulic conductivity and water content dependence on the capillary pressure head. The van Genuchten-Mualem model is described as follows:

$$
\begin{aligned}
& \theta(h)= \begin{cases}\theta_{r}+\frac{\theta_{s}-\theta_{r}}{\left[1+|\alpha h|^{n}\right]^{m}} & h<0 \\
\theta_{s} & h \geq 0\end{cases} \\
& S_{e}(h)=\frac{\theta(h)-\theta_{r}}{\theta_{s}-\theta_{r}} \\
& K(h)=K_{s} S_{e}^{l}\left[1-\left(1-S_{e}{ }^{1 / m}\right)^{m}\right]^{2} \\
& m=1-1 / n, \quad n>1,
\end{aligned}
$$

where $\theta(h)$ is the volumetric water content at the pressure head $h[-], \theta_{s}$ and $\theta_{r}$ - the saturated and residual volumetric water contents [-], respectively; $S_{e}(h)$ - the degree of saturation at the pressure head $h[-], K_{s}-$ the saturated hydraulic conductivity [L $\left.\mathrm{T}^{-1}\right], \alpha\left(\mathrm{L}^{-1}\right)$ and $n[-]$ are van Genuchten's shape parameters, and $l$ is a tortuosity or pore connectivity parameter estimated by Mualem (1976) to be 0.5 . Eqs. (5) and (6) have been used with or without additional modifications to model variablysaturated water flow and have been successfully extended into two and three dimensions (e.g., Pruess et al., 2004 or Šimůnek et al., 2006).

\section{SILF inverse formulation}

Šimůnek and Hopmans (2002) and Hopmans et al. (2002) provide a detailed description of the SSQ approach for estimating soil hydraulic parameters using inverse modeling. For an inverse modeling problem involving multiple measurement sets of size $q_{i}$, the SSQ-based objective function $\varphi$ used in HYDRUS-1D (Šimůnek et al., 2005) is mathematically described as

$$
\varphi(Y(\delta), \tilde{y}, \delta)=\sum_{i=1}^{p} u_{i} \sum_{j=1}^{q_{i}} v_{i, j}\left[Y_{i, j}(\delta)-\tilde{y}_{i, j}\right]^{2},
$$

where $p$ is the number of measurement sets, $u_{i}$ - the weight corresponding to each measurement set, $v_{i, j}$ - the weight corresponding to the $j^{\text {th }}$ data point of the $i^{\text {th }}$ measurement set, $\delta$ - the parameter set (as described earlier in (1)), $\tilde{y}_{i, j}-$ the $j^{\text {th }}$ data point of the $i^{\text {th }}$ measurement set and $Y_{i, j}(\delta)$ is the corresponding model prediction.

In the HYDRUS software, the MarquardtLevenberg algorithm (Marquardt, 1963) is used to optimize the objective function. The MarquardtLevenberg algorithm combines the Newton and steepest descent methods, and provides confidence intervals for the optimized parameters. It should be noted that the Marquardt-Levenberg algorithm is a local minimization approach seeking a local minimum in the vicinity of the initial estimate of optimized parameters, requiring reasonable initial estimates of parameters. There are other local and global optimization approaches that could be also considered to solve the optimization problem. Readers are referred to the above referenced literature (e.g., Šiminek and Hopmans, 2002; Hopmans et al., 2002; Vrugt et al., 2005, 2008) for more details. The proposed SILF methodology essentially uses the same solution framework as SSQ. The only difference between the SSQ and SILF based approaches is the definition of the objective function.

To ensure the robustness of the objective function in estimating parameter values during inverse modeling, a good understanding of the nature of measurement errors in collected datasets is needed (e.g., Roth et al., 1990; Simuinek and van Genuchten, 1996). Most statistical methods, such as SSQbased inverse modeling, are based on the assumption of homoscedastic and Gaussian errors. Gaussian errors have a similar variance that is independent of the 'true' value of a particular variable. However, one often encounters data when observing natural processes wherein the error variance is directly related to the 'true' variable value. Such errors are referred to as heteroscedastic errors. Homoscedastic errors may be considered as a special case of heteroscedastic errors with a heteroscedastic variance of zero. Considering the error distribution of typically observed soil data and inspired by the SILF objective function, we propose for inverse 
modeling of vadose zone processes the SILF-based objective function $\tau$ that uses relative errors instead of absolute errors as follows:

$$
\tau(Y(\delta), \tilde{y}, \delta)=\sum_{i=1}^{p} u_{i} \sum_{j=1}^{q_{i}} v_{i, j}\left[l_{i, j}(\delta)\right]^{2}
$$

where

$$
l_{i, j}(\delta)= \begin{cases}\left|Y_{i, j}(\delta)-\tilde{y}_{i, j}\right|-\varepsilon \tilde{y}_{i, j} & \frac{\left|Y_{i, j}(\delta)-\tilde{y}_{i, j}\right|}{\tilde{y}_{i, j}}>\varepsilon \\ 0 & \frac{\left|Y_{i, j}(\delta)-\tilde{y}_{i, j}\right|}{\tilde{y}_{i, j}} \leq \varepsilon\end{cases}
$$

where symbols represent parameters, observations and model predictions as described earlier in Eqs. (3) through (6).

The parameter set, $\delta$, to be estimated may include any combination of soil hydraulic parameters, such as $\theta_{s}, \theta_{r}, K_{s}, \alpha, n$ and $l$. The observed data set can include observed water contents, $\theta(t)$, pressure heads, $h(t)$ and/or instantaneous or cumulative boundary fluxes, $q(t)$ (e.g., infiltration or outflow data) at different times and locations, or retention, $h(\theta)$, or hydraulic conductivity, $K(h)$, data. One may observe that the SILF-based objective function, $\tau$, attains the form of the weighted Root Mean Squared Error (RMSE) approach (which is linearly related to the SSQ-based objective function $\varphi$ defined by Eq. (7)) when the acceptable error $\varepsilon$ is equal to zero. The SSQ-based and SILF-based inverse models thus estimate the same parameter sets when the acceptable error is zero. Similarly, when observed dataset involves only homoscedastic errors, the acceptable error $\varepsilon$ may be multiplied by one instead of the observed value $\tilde{y}_{i, j}$.

In the SILF-based objective function $\tau$ (Eq. (8)), the insensitivity of the error is considered on a relative basis. The error is considered to be significant only if the ratio of the absolute residual $e_{i}(\delta)$ to the observed value is greater than the acceptable error, $\varepsilon$. In scenarios wherein the soil measurements suffer from heteroscedastic errors, the SILF-based objective function may be expected to show an improvement in fitting the observed data.

The performance of the SILF objective function is strongly dependent on the choice of $\varepsilon$ (Kecman, 2001, Hastie et al., 2001). For example, one cannot expect reliable estimates of parameters if $\varepsilon$ is larger than the range of the observed data. On the contrary, when the acceptable error $\varepsilon$ is zero (same as
SSQ), the objective function may overfit measured data by fitting measurement errors (Hastie et al., 2001). The value of $\varepsilon$ must therefore be selected so that it reflects the statistical distribution of errors in the measured data in some way. Several researchers have pointed out a direct linear dependence of the optimal value of $\varepsilon$ on the noise in the observed data (Kwok and Tsang, 2003; Smola et al., 1998). The optimal $\varepsilon$ has been suggested to be between 0.6 and 1.0 times the variance of the noise in the observed data set. One may thus choose the optimal value of $\varepsilon$ when the variance of noise in the observed data is known. For the SILF objective function described in (8), one may use an acceptable error that is 0.6-1.0 times the relative sensitivity of the measuring instrument.

In many cases, the variance of the observed data is not known. It may then be of interest to estimate the noise in the observed data for quality assurance and quality control purposes during the parameter optimization process. In such case we suggest the following approach: (a) vary the acceptable error, $\varepsilon$, from zero to a certain maximum value at equal intervals, (b) perform inverse modeling using the SILF approach, (c) estimate the Root Mean Squared Error (RMSE) between the observed and predicted data, and (d) choose the optimal value of $\varepsilon$ that corresponds to the minimum RMSE.

The SILF formula was implemented in the inverse modeling framework of the HYDRUS-1D software package (Šimůnek et al., 2005). No additional changes of the model were needed since the rest of the inverse modeling framework for the SILF approach is the same as for the SSQ approach. We then analyzed the performance of the SILF approach by considering two sets of case studies. In the first case, the soil hydraulic parameters were estimated using inverse modeling for a hypothetical numerical one-step outflow experiment, in which the observed data sets were created by perturbing true values (model-generated) with heteroscedastic noises of varying levels. In the second case, we compared the performance of the SILF and SSQ approaches for several tutorial examples supplied with the HYDRUS-1D software.

\section{Case studies}

\section{Case Study 1: Numerical analysis of a one-step outflow experiment}

In the first case study, we consider the inverse solution of a one-step outflow experiment. The 
experiment is setup based on the problem presented by $\mathrm{Kool}$ et al. (1985). The soil profile, consisting of a $3.95-\mathrm{cm}$ long soil sample and a $0.57-\mathrm{cm}$ thick ceramic plate, is discretized using 50 nodes, five of which represent the ceramic plate. Only a few discretization nodes were needed in the ceramic plate since the plate remains saturated during the entire experiment, thus causing the flow process in the plate to be linear. Outflow is initiated using a pressure head of $-10 \mathrm{~m}$ imposed on the lower boundary. The direct problem was first solved using the following soil hydraulic parameters: $\theta_{r}=0.187, \theta_{s}=$ $=0.388, \alpha=0.042 \mathrm{~cm}^{-1}, n=1.535, K_{s}=5.4 \mathrm{~cm} \mathrm{~h}^{-1}$, $K_{s}$ (of the ceramic plate) $=0.3 \mathrm{~cm} \mathrm{~h}^{-1}$, and $l=0.5$, to calculate cumulative bottom fluxes at selected time steps that were assumed to represent the 'true'/unperturbed observed data set $\tilde{y}_{i}$ for the inverse problem. Perturbed data sets of varying noise levels were then created as follows:

$y_{i}^{*}(\xi)=\tilde{y}_{i}\left[1 \pm \xi^{*} \psi(0,1)\right] \quad i=1 . . q$

where $q$ is the size of the observed data set (here $q$ $=9), \xi-$ a perturbation level that describes the magnitude of noise, $\psi(0,1)$ is a normally distributed random number, and $y p(\xi)$ is the perturbed observed data as a function of $\xi$. Fig. 2 shows the unperturbed (true) and perturbed cumulative bottom fluxes $(\xi=0.01,0.03,0.05$ and 0.07$)$ used in the numerical experiment. The goal of the inverse problem is to estimate soil hydraulic parameters, $\theta_{r}$, $\alpha$, and $n$, from observed cumulative bottom fluxes $y^{*}(\xi)$. Similarly as Kool et al. (1987), we assumed that $\theta_{s}$ and $K_{s}$ were measured independently and were thus known. Both SSQ and SILF approaches were used to estimate the soil hydraulic parameters using perturbed data sets. We used the same initial parameter estimates for the SSQ and SILF approaches to allow for a reasonable comparison of the inverse modeling results. The obtained soil hydraulic parameters were then compared to their true values.

The following key objectives were addressed in this analysis: (1) How well do the SILF and SSQ approaches fit the perturbed and underlying true observation data set? (2) How close to the 'true' parameter set are the soil hydraulic parameters estimated from perturbed observations using the SILF and SSQ approaches? And finally, (3) does the optimal acceptable error used in the SILF approach provide an information about the noise in observations?

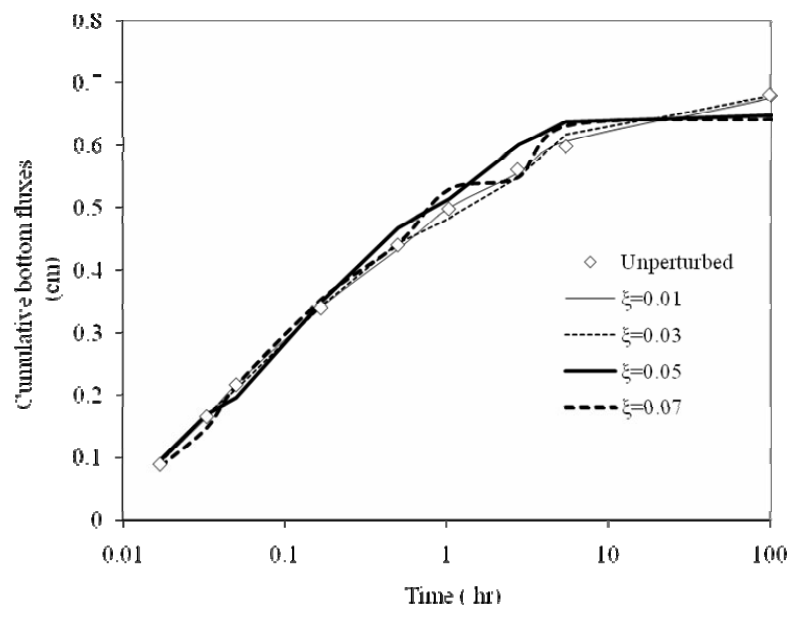

Fig. 2. Unperturbed (true) and perturbed observed data sets for different perturbation levels $(\xi=0.01,0.03,0.05$, and 0.07$)$ used in the numerical experiment.

Obr. 2. Pozorované údaje (nevyhladené reálne) a vyhladené údaje (s chybami merania a spracovania) pre rozdielne úrovne spracovania $(\xi=0,01 ; 0,03 ; 0,05$ a 0,07$)$, ktoré boli použité v numerických experimentoch.

The SILF and SSQ approaches were used to estimate the soil hydraulic parameters using the data sets perturbed with different levels of noise. As described earlier, the choice of the acceptable error is crucial to the efficiency of the SILF approach. In order to estimate the optimal value of the acceptable error, a thorough search was performed as described earlier. The optimal value of the acceptable error minimizes the Root Mean Squared Error $\left(\mathrm{RMSE}_{\mathrm{p}}\right)$ between the perturbed data and model predictions

$R M S E_{p}=\sqrt{\frac{\sum_{i=1}^{q}\left(Y_{i}(\delta)-y p_{i}\right)^{2}}{q}}$,

where $Y_{i}(\delta)$ is the model-predicted data that is calculated using the parameter set $\delta$ estimated from the perturbed observed data set. As an example, Fig. 3 shows the variation of the SILF-based function, $\tau$, and the $\mathrm{RMSE}_{\mathrm{p}}$ (between predicted values and observed data with the perturbed level $\xi=0.03$ ) for inverse solutions with different acceptable errors. It is interesting to observe that the solution obtained using the SSQ approach does not produce the minimal $\mathrm{RMSE}_{\mathrm{p}}$ even though the SSQ objective function is designed to minimize $\mathrm{RMSE}_{\mathrm{p}}$. The $\mathrm{RMSE}_{\mathrm{p}}$ is minimized with an acceptable error $\varepsilon=$ $=0.031$ for the perturbed data set of $\xi=0.03$. Similar analysis carried on all perturbed data sets shows 
a nearly 1:1 relationship between the optimal acceptable error and the perturbation level $\xi$ of the data set. Fig. 4 shows a plot between the optimal acceptable error $\varepsilon$ estimated with the SILF approach and the perturbation level $\xi$ of the perturbed data set. The observed linear trend between these two variables is consistent with the observations made in earlier applications of the SILF approach elsewhere (Smola et al., 1998). Similarly to Smola et al. (1998), a strong linear relationship exists also in our analysis $\left(\varepsilon=0.95 \xi ; \mathrm{R}^{2}=0.97\right)$. This result is very useful as it indicates that measurement errors, as a result of instrument sensitivity during vadose zone sampling, can be estimated indirectly using inverse modeling.

One of the biggest strengths of the SILF approach is the robustness in capturing the underlying functional relationship despite of errors in data sets (Hastie et al., 2001; Vapnik, 1995). Parameter sets estimated using different perturbed data sets were used to calculate cumulative outflow fluxes, which were then compared to the corresponding perturbed

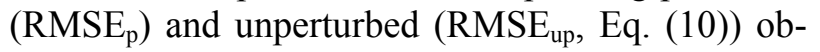
servations.

$R M S E_{u p}=\sqrt{\frac{\sum_{i=1}^{q}\left(Y_{i}(\delta)-\tilde{y}_{i}\right)^{2}}{q} .}$

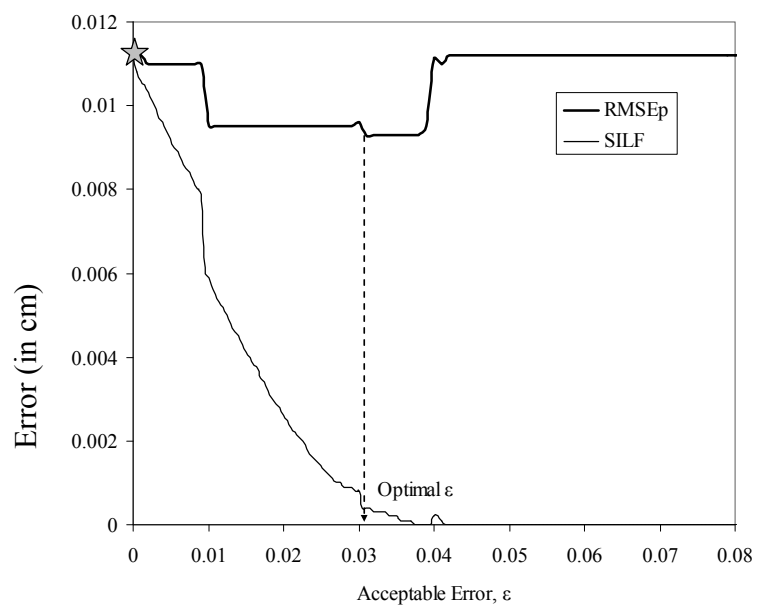

Fig. 3. SILF and $\mathrm{RMSE}_{\mathrm{p}}$ for the perturbed data set $(\xi=0.03)$ in the SILF approach as a function of the acceptable error. The star symbol indicates $\mathrm{RMSE}_{\mathrm{p}}$ for the SSQ approach. The error indicates the optimal estimate of the acceptable error.

Obr. 3. SILF a RMSE pre súbor vyhladených údajov $(\xi=$ $0.03)$ pre SILF ako funkcia akceptovatel'nej chyby. Hviezdička označuje $\mathrm{RMSE}_{\mathrm{p}}$ pre SSQ. Chyba označuje optimálnu prijatel'nú chybu.

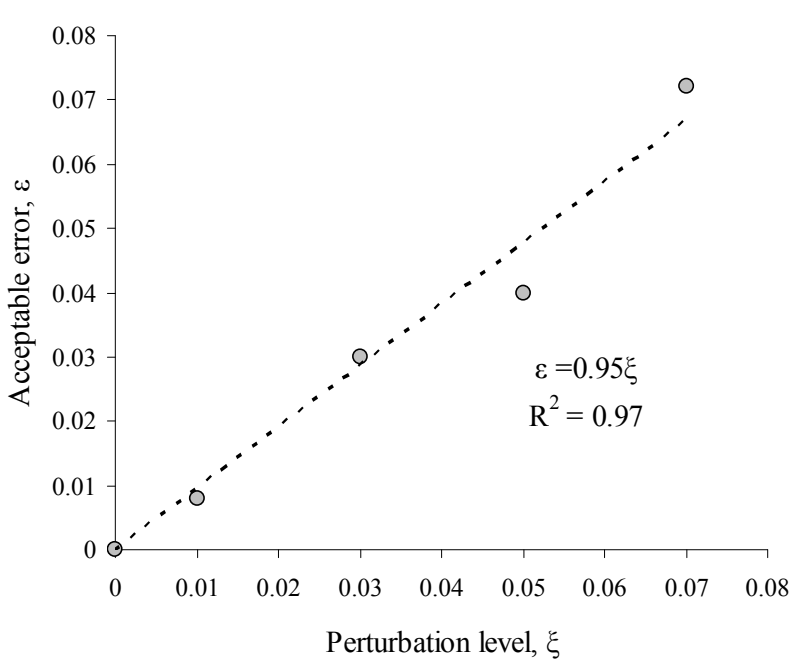

Fig. 4. Relationship between the estimated optimal acceptable error and the perturbation level. Note that the strong linear dependency is similar to that suggested by Smola et al. (1998). Obr. 4. Vzt’ah medzi určenou optimálnou prijatel'nou chybou a úrovňou vyhladenia chýb. Všimnite si, že lineárna závislost' je podobná tej, ktorú navrhol Smola et al. (1998).

Tab. 1 shows estimates of RMSE $E_{u p}$ and $\mathrm{RMSE}_{\mathrm{p}}$ for cumulative outflow fluxes using soil hydraulic parameter sets estimated using inverse analysis of different perturbed data sets. An obvious observation in Tab. 1 (as previously seen in Fig. 3) is that the SILF approach seems to have smaller RMSE values than SSQ approach for all perturbation levels. It can therefore be concluded that the SILF approach is an improvement over SSQ for inverse modeling purposes. Another interesting observation in Tab. 1 is the relative magnitude of $\mathrm{RMSE}_{\text {up }}$ and $\mathrm{RMSE}_{\mathrm{p}}$. At low perturbation levels, the RMSE $\mathrm{Ep}_{\text {up }}$ is smaller than the $\mathrm{RMSE}_{\mathrm{p}}$ indicating that both approaches (SSQ and SILF) seem to capture the underlying hydrological process well in spite of the noise in the data set. However, when perturbation levels are high enough $(\xi=0.07)$ for the noise in the data set to override the hydrological information, both SSQ and SILF (to a lesser extent as indicated by the smaller $\mathrm{RMSE}_{\mathrm{p}}$ and $\mathrm{RMSE}_{\mathrm{up}}$ ) approaches seem to lose their generalization ability and fail to capture the underlying functional relationship, resulting in $\mathrm{RMSE}_{\text {up }}$ being greater than $\mathrm{RMSE}_{\mathrm{p}}$. Tab. 2 compares the soil hydraulic parameters estimated using the SILF and SSQ approaches from different data sets to their 'true' values. Parameters estimated using the SILF approach are in general closer to the 'true values' than those estimated using the SSQ approach. 
T a b 1 e 1. Root Mean Squared Errors (RMSE) between observed bottom water fluxes (perturbed and unperturbed) and those calculated with parameters estimated using inverse analysis of the onestep outflow experiment.

T a b u l'k a 1. RMSE medzi tokmi vody pozorovanými cez dolnú plochu vzorky pôdy (merané a vyhladené), ako aj vypočítané s parametrami určenými inverznou analýzou jednostupňového výtokového experimentu.

\begin{tabular}{lccccc}
\hline \multirow{2}{*}{$\begin{array}{l}\text { Perturbation } \\
\text { level, } \xi\end{array}$} & $\begin{array}{c}\text { Acceptable error, } \\
\varepsilon\end{array}$ & \multicolumn{2}{c}{ RMSE $_{\mathrm{p}}\left[\times 10^{-3} \mathrm{~cm}\right]$} & \multicolumn{2}{c}{$\mathrm{RMSE}_{\text {up }}\left[\times 10^{-3} \mathrm{~cm}\right]$} \\
\cline { 3 - 6 } & 0.00 & 0.00 & 0.00 & $\begin{array}{c}\text { SSQ } \\
\text { approach }\end{array}$ & $\begin{array}{c}\text { SILF } \\
\text { approach }\end{array}$ \\
\hline 0.00 & 0.008 & 3.90 & 3.89 & 0.00 & 0.00 \\
0.01 & 0.030 & 11.20 & 9.30 & 3.56 & 3.3 \\
0.03 & 0.040 & 20.40 & 20.30 & 15.32 & 2.96 \\
0.05 & 0.072 & 18.52 & 18.39 & 20.43 & 14.85 \\
0.07 & & & & \\
\hline
\end{tabular}

$\mathrm{T}$ a b 1 e 2. Soil hydraulic parameters $\left(\theta_{r}, \alpha\right.$, and $\left.n\right)$ estimated from the unperturbed and perturbed data sets using the SSQ and SILF approaches. The values in parentheses are the estimates of $95 \%$ confidence intervals.

$\mathrm{T}$ a b u l' k a 2. Hydraulické parametre pôdy $\left(\theta_{r}, \alpha\right.$, a $\left.n\right)$ určené z nameraných a vyhladených hodnôt pomocou procedúr SSQ a SILF. Hodnoty v zátvorkách sú odhady s $95 \%$ pravdepodobnostou výskytu.

\begin{tabular}{ccccc}
\hline $\begin{array}{c}\text { Inverse approach and } \\
\text { data set used }\end{array}$ & $\begin{array}{c}\text { Acceptable } \\
\text { error } \varepsilon\end{array}$ & $\theta_{r}$ & $\alpha$ & $n$ \\
\hline SSQ/SILF $(\xi=0.00)$ & 0.00 & 0.187 & 0.042 & 1.535 \\
& & $(0.186,0.188)$ & $(0.041,0.043)$ & $(1.534,1.536)$ \\
SSQ $(\xi=0.01)$ & - & $(0.171,0.191)$ & $(0.034,0.045)$ & $(1.428,1.551)$ \\
& & 0.182 & 0.040 & 1.510 \\
SILF $(\xi=0.01)$ & 0.008 & $(0.174,0.191)$ & $(0.036,0.043)$ & $(1.432,1.544)$ \\
& & 0.169 & 0.034 & 1.424 \\
SSQ $(\xi=0.03)$ & - & $(0.140,0.197)$ & $(0.020,0.047)$ & $(1.324,1.522)$ \\
& & 0.179 & 0.039 & 1.474 \\
$\operatorname{SILF}(\xi=0.03)$ & 0.030 & $(0.149,0.191$ & $(0.024,0.043)$ & $(1.354,1.531)$ \\
& & 0.178 & 0.053 & 1.630 \\
$\operatorname{SSQ}(\xi=0.05)$ & - & $(0.118,0.238)$ & $(0.011,0.081)$ & $(1.069,2.001)$ \\
& & 0.187 & 0.046 & 1.535 \\
$\operatorname{SILF}(\xi=0.05)$ & 0.040 & $(0.128,0.214)$ & $(0.018,0.061)$ & $(1.169,1.893)$ \\
& & 0.119 & 0.021 & 1.299 \\
$\operatorname{SSQ}(\xi=0.07)$ & - & $(0.052,0.186)$ & $(0.012,0.0304)$ & $(1.19,1.403)$ \\
& & 0.120 & 0.022 & 1.299 \\
$\operatorname{SILF}(\xi=0.07)$ & 0.072 & $(0.072,0.185)$ & $(0.014,0.0334)$ & $(1.22,1.39)$ \\
\hline
\end{tabular}

It may also be observed in Tab. 2 that parameters estimated using the SILF approach tend to have smaller confidence intervals than those estimated using the SSQ approach. The robustness of the inverse problem may be analyzed by plotting response surfaces (Hopmans et al., 2002). The response surface is obtained by solving the flow equation, with the appropriate boundary and initial conditions, for many possible combinations of a selected pair of parameters within their predetermined ranges, while keeping the other parameters constant. This type of analysis should also be done before the experiment is conducted to investigate the well-posedness of the inverse problem (Hopmans et al., 2002). Fig. 5 presents one set of response surfaces showing the variation of the SSQ (SILF with the acceptable error of zero) and SILF (for the optimal non-zero acceptable error) objective functions for the $\alpha$ and $n$ parameters for the inverse analysis with the perturbed data set $(\xi=$ $=0.03$ ). Even though $\theta_{r}$ is a parameter of interest in this exercise, we choose to discuss the response surface for $\alpha$ and $n$ parameters because the residual water content tends to be relatively insensitive to the inverse modeling procedure. For estimation of the response surface, we assumed $\theta_{r}$ to be the optimized value of 0.187 . The response surface of the SILF objective function with the optimal acceptable error indicates an improvement in inverse modeling. The greater slope of the response surface around the minimum of the SILF objective function implies smaller confidence intervals of optimized parameters. 

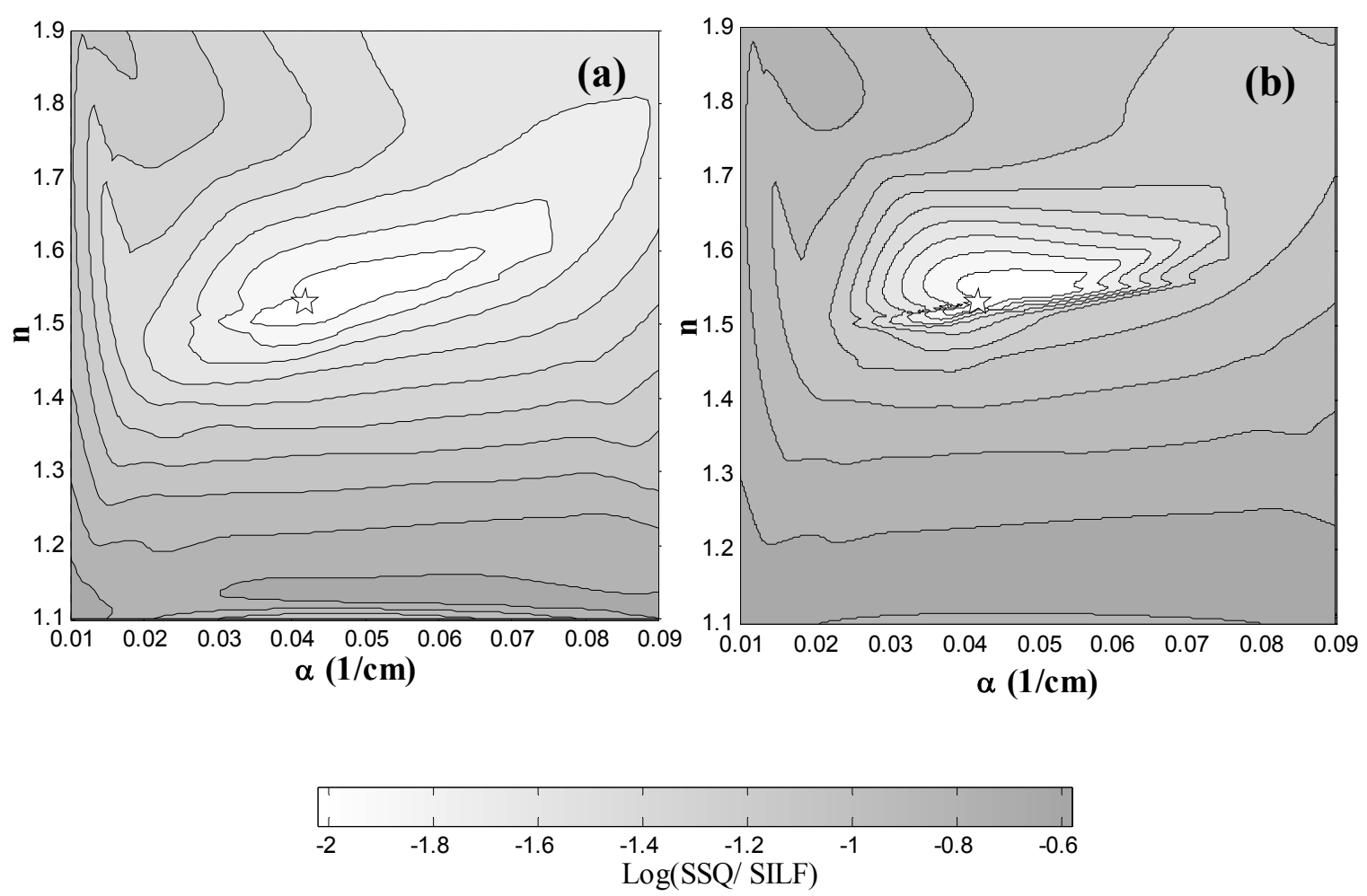

Fig. 5. Response surfaces indicating the sensitivity of the objective functions [(a) SSQ and (b) SILF] to the $\alpha$ an $n$ [-] parameters for the inverse analysis of the onestep outflow experiment using observed data perturbed with $\xi=0.03$. The star symbol indicates the location of the 'true' parameter set and $\theta_{r}=0.187$.

Obr. 5. Povrchy, indikujúce citlivost' optimalizovaných funkcií [(a) SSQ a (b) SILF] k parametrom $\alpha$ a $n$ [-] pre inverznú analýzu jednokrokového výtokového experimentu s využitím vyhladených údajov s $\xi=0,03$. Hviezdička označuje miesto "skutočného" súboru parametrov a $\theta_{r}=0,187$.

\section{Case Study 2: Tutorial examples from HYDRUS-1D}

Previous studies (such as Toorman et al., 1992, van Dam et al., 1992) have observed inverse modeling of one-step outflow experiments when the OF is composed exclusively of cumulative outflow data results in parameter estimates that are often unreliable and non-unique. In order to further verify if the SILF approaches universally improves the inverse modeling results, we performed a second case study that involved the analysis of the performance of the SSQ and SILF approaches for a variety of realworld examples. For this purpose we consider the following examples that are provided as tutorials of inverse modeling and distributed with the HYDRUS-1D software package (http://www.pcprogress.com/en/Default.aspx?hydrus-1d): (a) horizontal flow and redistribution (Vachaud, 1968), (b) horizontal infiltration (Vachaud, 1968), (c) upward infiltration (Wierenga, personal communication), (d) drainage in a sand column (Vachaud, 1968), (e) multistep outflow experiment (Hopmans, personal communication), and (f) transient flow involving hysteresis (Vogel et al., 1996). Tab. 3 lists the type of observed data and estimated parameters in each of these examples, as well as the RMSE estimates for predictions using the SSQ and SILF approaches. In each of these case studies that cover a variety of real-world vadose zone flow experiments, the SILF approach exhibits an improvement in parameter estimation (lower RMSE). Even though the improvement is not significant for some cases, the presence (even if, insignificant) of an improvement over SSQ approach indicates the need for further exploration in to the efficacy of the SILF approach. We would like to note that the SILF approach is interesting for two reasons: (a) presence of an improvement in parameters over the SSQ approach as well as (b) estimation of an acceptable error that provides an insight to the accuracy of the experiments. 
$\mathrm{T}$ a b $1 \mathrm{e}$ 3. Performance of the SSQ and SILF approaches in estimating the soil hydraulic parameters for the selected HYDRUS1D tutorial problems.

T a b u l' k a 3. Výsledok aplikácie procedúr SSQ a SILF na určenie hydraulických parametrov pôdy pre vybraný príklad modelu HYDRUS-1D; 1 - horizontálne prúdenie a redistribúcia; 2 - horizontálna infiltrácia, 3 - infiltrácia vertikálne nahor, 4 - drenáž pieskovej vzorky pôdy, 5 - viackroková výtoková metóda, 6 - neustálené prúdenie s hysterézou.

\begin{tabular}{|c|c|c|c|c|c|}
\hline \multirow[t]{2}{*}{ Inverse model } & \multirow{2}{*}{$\begin{array}{l}\text { Observed data } \\
\text { [units] }\end{array}$} & \multirow{2}{*}{$\begin{array}{l}\text { Estimated para- } \\
\text { meters }\end{array}$} & \multirow{2}{*}{$\begin{array}{c}\text { RMSE in } \\
\text { SSQ approach }\end{array}$} & \multicolumn{2}{|c|}{ SILF approach } \\
\hline & & & & $\begin{array}{l}\text { Acceptable } \\
\text { error, } \varepsilon\end{array}$ & RMSE \\
\hline $\begin{array}{l}\text { Horizontal flow } \\
\text { and redistribution }\end{array}$ & $\theta(t)[-]$ & $\theta_{s}, \theta_{r}, \alpha, n, K_{s}, l$ & 0.0261 & 0.01 & 0.0257 \\
\hline $\begin{array}{l}\text { Horizontal infiltra- } \\
\text { tion }^{2)}\end{array}$ & $\theta(t)[-]$ & $\theta_{s}, \theta_{r}, \alpha, n, K_{s}, l$ & 0.0412 & 0.05 & 0.0396 \\
\hline $\begin{array}{l}\text { Upward Infiltra- } \\
\text { tion }^{3)}\end{array}$ & $\begin{array}{l}h(\theta)[\mathrm{cm}], \\
\theta(t)[-] \\
h(t)[\mathrm{cm}] \\
q(t)\left[\mathrm{cm} \mathrm{s}^{-1}\right]\end{array}$ & $\theta_{r}, \alpha, n, K_{s}, l$ & 3.7378 & 0.01 & 3.7336 \\
\hline $\begin{array}{l}\text { Drainage in a sand } \\
\text { column }\end{array}$ & $\theta(t)[-]$ & $\theta_{r}, \alpha, n, K_{s}, l$ & 0.0144 & 0.15 & 0.0140 \\
\hline $\begin{array}{l}\text { Multistep outflow } \\
\text { experiment } 5 \text { ) }\end{array}$ & $\begin{array}{l}\mathrm{h}(\mathrm{t})[\mathrm{cm}] \\
\mathrm{q}(\mathrm{t})\left[\mathrm{cm} \mathrm{s}^{-1}\right]\end{array}$ & $\theta_{s}, \theta_{r}, \alpha, n, K_{s}, l$ & 7.6298 & 0.15 & 7.5221 \\
\hline $\begin{array}{l}\text { Transient flow } \\
\text { involving hystere- } \\
\text { sis }{ }^{6)}\end{array}$ & $\begin{array}{l}h(t)[\mathrm{cm}] \\
\theta(t)[-]\end{array}$ & $\alpha, \alpha_{w}{ }^{*}, n$ & 4.6059 & 0.06 & 4.6043 \\
\hline
\end{tabular}

\section{Summary and conclusions}

Previous studies (such as Finsterle and Najita, 1998) have concentrated on robust estimators that were designed for tackling outliers in the data sets. Another small, yet significant, source of error that needs to be addressed during inverse modeling is the effect of measurement errors that are a result of instrument sensitivity and detection limits. We hypothesized that consideration of measurement errors in the inverse modeling process is bound to further improve the reliability of parameter estimation.

In this paper we evaluated an inverse analysis of vadose zone flow processes to estimate soil hydraulic parameters wherein the measurement errors were considered. The proposed method, called the SILF approach, is based on the objective function that uses the squared $\varepsilon$-insensitive loss function proposed by Vapnik (1995) that sums up quadratically transformed estimates of residuals whose absolute values are above a pre-defined threshold level (called the acceptable error). The SILF approach thus decreases the cumulative impact of smaller measurement errors by not penalizing them in the objective function. The performance of the SILF approach was tested on a variety of case studies and compared to the standard non-linear leastsquare approach (SSQ), in which the acceptable error is always set to zero. The SILF approach shows an improvement over the traditionally used SSQ approach and provides more robust estimates of soil hydraulic parameters.

One of the key requirements of the SILF approach is an apriori estimate of the acceptable error $\varepsilon$. As shown in this paper, when information regarding the acceptable error is not available, it can be estimated (although it is time consuming) simultaneously with the soil hydraulic parameters using a thorough, iterative, search-based technique. Apart from improved estimates of the soil hydraulic parameters over SSQ, the SILF approach can thus provide information about the level of noise in observed data sets (the optimal acceptable error) that may be used for quality control purposes at a later stage. The estimated optimal acceptable error also provides an approximation of the relative measurement and sampling errors caused during data collection stage. For inverse models based on realworld experiments, we believe that the value of acceptable error to be used can depend on the instrumentation or measurement errors involved. In cases where such data is not available, the acceptable error has to be selected on a trial-and-error basis.

There are many different types of errors associated with measurements that should be taken into account. Even though the currently proposed approach lumps all kinds of errors together, estimation of hydraulic parameters may improve if these 
errors can be separated in terms of their sources. This is one of the areas of future research. The SILF approach is expected to be useful in other hydrological inverse modeling/parameter estimation problems, especially when apparent measurement and/or sampling errors are expected in observations and when the number of empirical model parameters is large so that the model has the flexibility to over-fit the data. Application of the SILF approach to other hydrological problems is also a topic of our future research interest.

\section{List of symbols}

$E(\delta) \quad-$ residual vector [-],

$h \quad-$ soil water pressure head [L],

$K(h) \quad$ - unsaturated hydraulic conductivity as a function of $h\left[\mathrm{~L} \mathrm{~T}^{-1}\right]$,

$K_{s} \quad$ - saturated hydraulic conductivity $\left[\mathrm{L} \mathrm{T}^{-1}\right]$,

$l \quad-$ tortuosity or pore connectivity parameter $[-]$,

$n \quad-$ van Genuchten's shape parameter [-],

$p \quad-$ number of measurement sets,

$\mathfrak{R}^{s} \quad-s$-dimensional Euclidean space $[-]$,

$S \quad-$ sink term $\left[\mathrm{L} \mathrm{T}^{-1}\right]$,

$S_{e}(h) \quad-$ degree of saturation at the pressure head $h[-]$,

$t \quad$ - time [T],

$u_{i} \quad-$ weight corresponding to each measurement set,

$W_{i} \quad-$ weight vector [-],

$\gamma() \quad-$. linear/non-linear transformation function $[-]$,

$y^{*}(\xi) \quad-$ perturbed observed data as a function of $\xi$,

$z \quad-$ distance from reference datum [L],

$\alpha \quad-$ van Genuchten's shape parameter $\left[\mathrm{L}^{-1}\right]$,

$\varepsilon \quad-$ acceptable error [-]

$\Theta \quad-$ feasible parameter space $[-]$,

$\theta \quad-$ volumetric water content $[-]$,

$\theta(h) \quad-$ volumetric water content at the pressure head $h[-]$,

$\theta_{s} \quad-$ saturated volumetric water contents [-],

$\theta_{r} \quad-$ residual volumetric water contents [-],

$v_{i, j} \quad-$ weight corresponding to the $j^{\text {th }}$ data point of the $i^{\text {th }}$ measurement set,

$\tilde{y}_{i, j} \quad-j^{\text {th }}$ data point of the $i^{\text {th }}$ measurement set,

$\xi$ - perturbation level that describes the magnitude of noise,

$\psi(0,1) \quad$ - normally distributed random number,

$Y(\delta)=\left\{Y_{1}(\delta), Y_{2}(\delta), \ldots, Y_{q}(\delta)\right\}$ - model predictions using a parameter set $\delta[-]$,

$\tilde{\mathrm{y}}=\left\{\tilde{y}_{1}, \tilde{y}_{2}, \ldots, \tilde{y}_{q}\right\} \quad-$ vector of observed state variables of size $q[-]$,

$\delta=\left\{\delta_{1}, \delta_{2}, \ldots, \delta_{s}\right\}$

- parameter set of size $s[-]$.

\section{REFERENCES}

BROOKS R.H., COREY A.T., 1964: Hydraulic properties of porous media, Colorado State University, Fort Collins.

DIRKSEN C., 1991: Unsaturated hydraulic conductivity. In Smith, K.A., and C.E.Mullins, Soil analysis: physical methods. Marcel Dekker, New York. p. 209-269.

ECHING S.O., HOPMANS J. W., 1993: Optimization of hydraulic functions from transient outflow and soil water pressure data. Soil Science Society of America J., 57, 5, $1167-1175$
FINSTERLE S., NAJTA J., 1998: Robust estimation of hydrologic model parameters. Water Resour. Res., 34, 11, 2939 $-2947$.

GARDNER W.R., 1958: Some steady state solutions of unsaturated moisture flow equations with applications to evaporation from a water table. Soil Sci. Society of Amer. J., 85, 228-232.

HASTIE T., TIBSHIRANI R., FRIEDMAN J., 2001: The Elements of Statistical Learning: Data Mining, Inference and Prediction. Springer, New York.

HOPMANS J. W., CLAUSNITZER V., KOSUGI K.I., NIELSEN D.R., SOMMA F., 1997: Vadose zone measurement and modeling. Sci. agric. (Piracicaba, Braz.), 54, 22-26, ISSN 0103-9016.

HOPMANS J.W., ŠIMU゚NEK J., ROMANO N., DURNER W., 2002: Inverse Modeling of Transient Water Flow, In: Methods of Soil Analysis, Part 1, Physical Methods, Chapter 3.6.2, Eds. J. H. Dane and G. C. Topp, Third edition, SSSA, Madison, WI, 963-1008.

JURY W.A., GARDNER W.R., GARDNER W.H., 1991: Soil physics. 5th ed. John Wiley and Sons, New York.

KECMAN V., 2001: Learning and Soft Computing, SVM, NN, and FLS. The MIT Press, Cambridge, MA. URL: http://support-vector.ws

KLUTE A., DIRKSEN C., 1986: Conductivities and diffusivities of unsaturated soils. In: A. Klute (ed.). Methods of soil analysis. Part 1. 2nd ed. Agronomy Monograph 9, ASA and SSSA, Madision, WI. p. 687-734.

KOOL J.B., PARKER J.C., 1987: Estimating soil hydraulic functions from transient flow experiments: SFIT User's Guide. Soil and Environmental Sciences, Virginia Polytechnic Institute and State University, Blacksburg, VA.

KOOL J.B., PARKER J.C., VAN GENUCHTEN M.TH., 1985: Determining soil hydraulic properties for one-step outflow experiments by parameter estimation. I. Theory and numerical studies. Soil Sci. Society of Amer. J., 49, 1348$-1354$.

KWOK J.T., TSANG I.W., 2003: Linear Dependency between $\varepsilon$ and the Input Noise in $\varepsilon$-Support Vector Regression. IEEE Transactions on Neural Networks, 14, 3, 544-553.

LEIJ F.J., RUSSELL W.B., LESCH S.M., 1997: Closed-form expressions for water retention and conductivity data, Groundwater, 35, 848-858.

MARQUARDT D.W., 1963: An algorithm for least-squares estimation of nonlinear parameters. J. Soc. Ind. Appl. Math., 11, 431-441.

MUALEM Y., 1976: New Model for Predicting Hydraulic Conductivity of Unsaturated Porous-Media. Wat. Resour. Res., 12, 3, 513-522.

PRUESS K., 2004: The TOUGH codes-A family of simulation tools for multiphase flow and transport processes in permeable media. Vadose Zone J., 3, 738-746.

RICHARDS L.A., 1931: Capillary conduction of liquids through porous media. Physics, 1, 318-333.

ROTH K., SCHULIN R., FLÜHLER H., ATTINGER W., 1990: Calibration of Time Domain Reflectometry for Water Content Measurement Using a Composite Dielectric Approach. Water Resources Research, 26, 10, 2267-2273.

ŠIMŮNEK J., VAN GENUCHTEN M.TH., 1996: Estimating unsaturated soil hydraulic properties from tension disc infiltrometer data by numerical inversion. Wat. Resour. Res., 32, 9, 2683-2696.

ŠIMƯNEK J., HOPMANS J.W., 2002: Parameter Optimization and Nonlinear Fitting. In: Methods of Soil Analysis, Part 1, 
Physical Methods, Chapter 1.7, Eds. J. H. Dane and G. C. Topp, Third edition, SSSA, Madison, WI, 139-157.

ŠIMU゚NEK J., VAN GENUCHTEN M.TH., ŠEJNA M., 2005: The HYDRUS-1D Software Package for Simulating the Movement of Water, Heat, and Multiple Solutes in Variably Saturated Media, Version 3.0, Department of Environmental Sciences, University of California Riverside, Riverside, CA, pp. 270.

ŠIMU゚NEK J., VAN GENUCHTEN M.TH., ŠEJNA M., 2008: Development and applications of the HYDRUS and STANMOD software packages, and related codes, Vadose Zone Journal, doi: 10.2136/VZJ2007.0077, Special Issue "Vadose Zone Modeling", 7, 2, 587-600.

SMOLA A.J., MURATA N., SCHOLKOPF B., MULLER K.R., 1998: Asymptotically optimal choice of - loss for support vector machines. In Proceedings, Intl. Conf. on Artificial Neural Networks (ICANN'98), 1, 105-110.

VACHAUD G., 1968: Contribution to the study of flow problems in unsaturated porous media. Theses presented at the Scholl in Physical Sciences of the Univ. of Grenoble, Grenoble, France, Catalog Number: A.O.2655, pp. 259.

VAN DAM J.C., STRICKER J.N.M., DROOGERS P., 1994: Inverse method for determining soil hydraulic functions from multi-step outflow experiments. Soil Sci. Soc. Amer. J., 58, 647-652.

VAN GENUCHTEN M.TH., 1980: A Closed-Form Equation for Predicting the Hydraulic Conductivity of Unsaturated Soils. Soil Sci. Society of Amer. J., 44, 5, 892-898.

VAPNIK V.N., 1995: The Nature of Statistical Learning Theory, Springer Verlag, New York.

VOGEL T., HUANG K., ZHANG R., VAN GENUCHTEN M.TH., 1996: The HYDRUS code for simulating onedimensional water flow, solute transport, and heat movement in variably-saturated media, Version 5.0, Research Report No. 140, U.S. Salinity laboratory, USDA, ARS, Riverside, CA.

VRUGT J.A., DIKS C.G.H., GUPTA H.V., BOUTEN W., VERSTRATEN J.M., 2005: Improved treatment of uncertainty in hydrologic modeling: Combining the strengths of global optimization and data assimilation. Wat. Resour. Res., 41, W01017, doi: 10.1029/2004WR003059.

VRUGT J.A., STAUFFER P.H., WÖHLING T., ROBINSON B.A. VESSELINOV V.V., 2008: Inverse modeling of subsurface flow and transport properties: A review with new developments. Vadose Zone J., doi:10.2136/VZJ2007.0078, Special Issue "Vadose Zone Modeling", 7, 2, 843-864.

YEH W.G., 1986: Review of parameter identification procedures in groundwater hydrology: The inverse problem. Wat. Resour. Res., 22, 2, 95-108.

Received 27 April 2009 Accepted 23 June 2010

\section{INVERZNÉ MODELOVANIE PRÚDENIA VODY VO VODOU NENASÝTENEJ PÔDE POUŽITÍM NECITLIVOSTNEJ STRATOVEJ FUNKCIE $\varepsilon$}

Navin K. C. Twarakavi, Hirotaka Saito, Jirka Šimůnek, M. Th. Van Genuchten

Predchádzajúce štúdie (ako napr. Finsterle a Najita, 1998) sa sústredili na robustné odhady eliminácie chýb v databázach. Ostatné sú malé, ale stále významné chyby, ktoré by mali byt' vylúčené počas inverzného modelovania, ako je vplyv chýb merania, ktoré sú dôsledkom citlivosti prístrojov a rozsahu merania. Predpokladali sme, že uváženie chýb merania počas inverzného modelovania je spojené s d'alším zvýšením spol'ahlivosti určenia parametrov.

V tejto práci sa hodnotí inverzná analýza prúdenia vody v nenasýtenej zóne pôdy, s uvážením chýb merania. Navrhnutá metóda nazvaná SILF je založená na použití kvadratickej, necitlivostnej stratovej funkcie s necitlivost'ou $\varepsilon$, navrhnutej Vapnikom (1995), sumujúcej kvadraticky transformované odhady reziduálov, ktorých absolútne hodnoty sú vyššie, ako preddefinovaný limit (nazývaný tiež akceptovatel'nou chybou).

Metóda SILF znižuje sumárny vplyv malých chýb merania tak, že ich nepenalizuje v optimalizačnej funkcii. SILF bol testovaný na viacerých prípadových štúdiách a výsledok bol porovnaný so štandardnou nelineárnou metódou najmenších štvorcov (SSQ), v ktorej je prijatel'ná chyba vždy nastavená na nulu. Tento prístup (SILF) je zlepšením tradične použivaného prístupu SSQ a výsledkom sú robustnejšie odhady hydraulických parametrov pôdy.

Jedným z kl'účových požiadaviek prístupu SILF je a priori určenie prijatel'nej chyby $\varepsilon$. Ako je to ukázané $\mathrm{v}$ tomto článku, ak nie je dostupná informácia o prijatel'nej chybe, potom táto chyba môže byt' určená (hoci je to časovo náročné) simultánne s hydraulickými parametrami pôdy pomocou iteratívnej techniky. Okrem zlepšených odhadov hydraulických parametrov pôdy v porovnaní s SSQ, prístup SILF dáva informácie o úrovni šumu v meraných hodnotách - optimálna akceptovatel'ná chyba, ktorá môže byt' využitá na neskoršiu verifikáciu. Optimálna akceptovatel’ná chyba dáva tiež aproximáciu relatívnych chýb merania a vzorkovania, počas zberu údajov. Sme presvedčení, že pre inverzné modelovanie, založené na meraniach, akceptovatel'ná chyba závisí od vlastností prístrojov a od chýb merania. V prípade neexistencie takýchto údajov, prijatel'ná chyba môže byt' vybraná postupom pokus - chyba.

Existuje množstvo chýb v dôsledku meraní, ktoré musia byt' vzaté do úvahy. Hoci bežne používaný postup združuje všetky druhy chýb, určenie hydraulických parametrov sa môže zlepšit', ak tieto chyby môžu byt' separované podl'a ich zdrojov. Toto je jednou z oblastí budúceho výskumu. Procedúra SILF bude pravdepodobne užitočná aj v iných metódach inverzného modelovania, resp. určovania parametrov, predovšetkým v prípadoch, ked' sa očakávajú chyby pri meraní a vzorkovaní a ked' je počet parametrov modelu väčší. Použitie procedúry SILF $\mathrm{v}$ iných hydrologických problémoch je predmetom d'alšieho výskumu.

Zoznam symbolov

$E(\delta) \quad$ - reziduálny vektor [-],

$h \quad-$ tlaková výška pôdnej vody [L], 
$K(h) \quad$ - nenasýtená hydraulická vodivost' ako funkcia $h$ $\left[\mathrm{L} \mathrm{T}^{-1}\right]$,

$K_{s} \quad-$ nasýtená hydraulická vodivost' $\left[\mathrm{L} \mathrm{T}^{-1}\right]$,

$l \quad-$ tortuozita, alebo parameter konektivity pórov [-],

$n \quad-$ van Genuchtenov tvarový parameter [-],

$p \quad$ - počet sérií meraní,

$\mathfrak{R}^{s} \quad-s$-rozmerný Euklidovský priestor $[-]$,

$S \quad$ - odberový člen $\left[\mathrm{L} \mathrm{T}^{-1}\right]$,

$S_{e}(h) \quad$ - nasýtenost' pri tlakovej výške $h[-]$,

$t \quad-$ čas $[\mathrm{T}]$

$u_{i} \quad$ - váha zodpovedajúca každej sérii merania,

$W_{i} \quad$ - váhový vektor [-],

$\gamma() \quad-$. lineárna/nelineárna transformačná funkcia [-],

$y^{*}(\xi) \quad$ - vyhladené pozorované údaje, ako funkcie $\xi$,

$z \quad-$ vzdialenost' od referenčnej úrovne [L],

$\alpha \quad-$ van Genuchtenov tvarový parameter $\left[\mathrm{L}^{-1}\right]$,

$\varepsilon \quad-$ akceptovatel'ná chyba [-]
$\Theta \quad$ - využitel'ný priestor parametrov $[-]$,

$\theta \quad$ - objemová vlhkost' [-],

$\theta(h) \quad-$ objemová vlhkost' pri tlakovej výške $h[-]$,

$\theta_{s} \quad-$ nasýtená objemová vlhkost' $[-]$,

$\theta_{r} \quad-$ reziduálna objemová vlhkost' $[-]$,

$v_{i, j} \quad-$ váha zodpovedajúca údaju $j^{\text {th }}$, sérii merania $i^{\text {th }}$,

$\tilde{y}_{i, j} \quad-$ údaj $j^{\text {th }}$ v sérii merania $i^{\text {th }}$,

$\xi \quad$ úroveň vyhladenia, ktorá je charakterizovaná úrovňou šumu,

$\psi(0,1) \quad$ - normálne rozdelenie náhodných čísel,

$\tilde{\mathrm{y}}=\left\{\tilde{y}_{1}, \tilde{y}_{2}, \ldots, \tilde{y}_{q}\right\} \quad-$ vektor pozorovanej stavovej premennej vel'kosti $q[-]$,

$Y(\delta)=\left\{Y_{1}(\delta), Y_{2}(\delta), \ldots, Y_{q}(\delta)\right\}$ - modelová predpoved' pomocou série parametrov $\delta[-]$,

$\delta=\left\{\delta_{1}, \delta_{2}, \ldots, \delta_{s}\right\} \quad$ - súbor parametrov vel'kosti $s[-]$. 